Article

\title{
Evaluating Public Policy Support for Agricultural Cooperatives
}

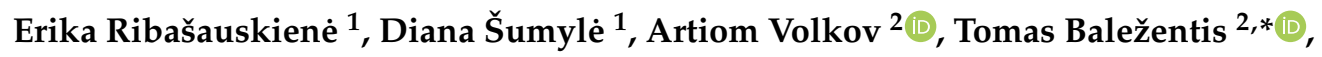 \\ Dalia Streimikiene $^{2}$ (D) and Mangirdas Morkunas ${ }^{3}$ \\ 1 Division of Rural Development, Lithuanian Institute of Agrarian Economics, V. Kudirkos St. 18-2, \\ 03105 Vilnius, Lithuania \\ 2 Division of Farms and Enterprises Economics, Lithuanian Institute of Agrarian Economics, V. Kudirkos St. \\ 18-2, 03105 Vilnius, Lithuania \\ 3 Faculty of Economics and Business, Mykolas Romeris University, Ateities St. 20, 08303 Vilnius, Lithuania \\ * Correspondence: tomas.balezentis@laei.lt
}

Received: 20 June 2019; Accepted: 4 July 2019; Published: 10 July 2019

check for updates

\begin{abstract}
Creation of a sustainable agricultural sector involves boosting the cooperation activities as these contribute to the societal and economic development of the farms, farmers and rural societies. This paper contributes to the literature on the analysis of the drivers and obstacles of cooperation development in agriculture. The case of Lithuania is considered as the cooperation activities are lagging behind the European Union (EU) practice here. Specifically, analysis of the public support measures and the expert survey are carried out to analyse the effectiveness of the public policy measures as represented in the relevant legal acts. The experts involve policy makers, farmers' organisations and academia, which are the major stakeholder groups in Lithuania. The results indicate the effectiveness of the measures linked to capacity building (in the sense of human capital) requires improvement, whereas those related to financial support and promotion of the farmers' organisations are much better perceived. Thus, public support measures are available to promote cooperation in agriculture, yet the legal system of Lithuania still requires improvement in accommodating effective agricultural cooperatives.
\end{abstract}

Keywords: agricultural cooperatives; cooperation development; expert survey; CAP measures; public policy; public support

\section{Introduction}

The EU Action Plan 2003 and the introduction of the European Cooperative Society (SCE) Statute in the same year as well as the outbreak of financial and economic crisis in 2008 highlighted the importance of cooperation. The agricultural sector is also related to cooperation activities. Although there is no evidence that Member States actively promote the organization of agricultural producers into cooperatives, cooperation is common in the EU and appears to be a common legal form for agricultural producers to organize their joint business activities [1,2].

Governments or supranational organizations have been encouraging cooperation in order to solve various socio-economic and environmental problems: reducing poverty in rural underdeveloped regions [3], changing market structure (usually associated with combating oligopolies) [4], providing lagging rural regions with necessary commodities [5], solving environmental and energy security issues [6-9], immaturity of financial markets [10], social inequality [11], testing new business organizational structures and its impact onto existing market structure [12,13], and restructuring planned economy to market oriented [14]. While cultural and historical experience is significant for the development of cooperatives, another element of the institutional environment may be even 
more important. This element is the impact of the state in its role as regulator and supporter of cooperatives [15]. EU countries experience shows that, the weaker the cooperatives are, the more the state is willing to support them and the more policy measures it suggests.

Compared with other EU member states, Lithuania faces subdued cooperation activities in agriculture. Only accredited cooperatives can apply for financial support under Lithuanian Rural Development Programme 2014-2020. In 2014, 44 cooperatives received accreditation, whereas, in 2017, only 22 cooperatives, or half of the previous number, were accredited. A decreasing number of cooperatives approved by the state may reveal, on the one hand, a declining interest of organized farmers in public support, or difficulties related to high standards dictated by the accreditation procedure. The EU-wide study has also shown that Lithuanian farmers did not make use of the notably supportive Lithuanian policy measures stimulating the creation and development of cooperatives [16]. Do these tendencies imply that public policy support in the Lithuanian case is ineffective? Is it one of the reasons behind slow cooperation development?

In spite of importance of the agricultural cooperation [17], the effectiveness and efficiency of government policies in support of cooperatives still require further research. In particular, no systematic or comprehensive attempts have been made to evaluate government support for cooperation in Lithuania. Therefore, the aim of this paper is to identify and evaluate public policy measures supporting the development of agricultural cooperatives in Lithuania and to make recommendations for the improvement of support policy. The subject of the research-public policy measures supporting the development of agricultural cooperatives. The main method applied in the research is expert interviews carried out in the form of a semi-structured survey with selected knowledgeable experts. It allowed ensuring data availability, reliability and representativeness.

The paper proceeds as follows: Section 2 discusses the theoretical premises for cooperation in agriculture. Section 3 proceeds with analysis of the public support for agricultural cooperation in Lithuania. Section 4 presents the methodological approach of the expert survey. The results of the expert survey are presented in Section 5. Finally, Section 6 provides the conclusions.

\section{Literature Review}

\subsection{The Rationale for Cooperation in Agriculture}

The idea of cooperation in agriculture is not new. Sometimes, it even played a prominent role in history. There is an abundance of literature showing that some form of agricultural cooperatives-the kibbutz-served as a predecessor for the Jewish state [18,19], and agricultural cooperatives in the USSR helped to solidify and legitimize communist rule [20,21]. The political side is observed in a formation of agricultural cooperatives also in our days. Fonte and Cucco [22] treat these loosely coordinated economic entities as a manifestation of social movements aimed at solving local problems of rural citizens, as these issues sometimes are being denied by local authorities as well as Government. This view is supported by Dillahunt et al., [23], who research agricultural cooperatives as a social security incentive for combating institutional voids in providing necessary instruments for self-sufficiency in poor communities. Agricultural cooperatives are serving as a platform for satisfying people's everyday needs, then the Government is failing to assure even the everyday needs of its citizens, which is also seen by Kurakin and Visser [24], who investigate the cases when Government intentionally transmits this responsibility to its own people in turbulent economic periods, thus stressing the fact that emergence of agricultural cooperatives is the result of external economic pressure on insecure rural citizens. It should be noted that some agricultural cooperatives are being built not as a response to external pressure [25], but on a spiritual basis [26], which guarantees the fulfilment of every party's obligations in a much better manner, requiring less costs and efforts for monitoring other cooperative members actions, although the main driving force for cooperation is economic benefits [27].

The new incentives towards agricultural cooperatives were raised with the introduction of the concept of sharing economy, which gains momentum in accommodation services [28-30]), 
car and ride [31], social commerce [32], art [33] and even employment [34]. Agriculture also appears in this emerging stream, showing renewed interest in various forms of cooperation: shared marketing activities [35], fund raising and self-financing [36], shortening and simplifying distribution networks [37], serving as Governmental tools for inducing changes in society, such as transforming its values to a more modern and tolerant basis [38], and helping to introduce modern management methods to the highly labor intensive agricultural sector [39]. The learning as well as information sharing and innovation creating abilities of agricultural cooperatives dominate Borgen and Aarset [40] research. Cooperatives also act as information sharing platforms [41], lowering transaction costs, providing a possibility to partial work division, allowing members of cooperatives to focus on activities they are performing best [42], etc. Lamine [43] sees agricultural cooperatives as one of the driving factors for more sustainable rural development. Swaminathan [44] stresses bigger bargaining power of agricultural cooperatives, allowing small farmers to receive more fair prices for their goods, although Zivkovic and Hudson [45] pay attention to nepotism and improper management practices of cooperatives, due to its clearly undefined state and the absence of formal rules, leading to diminishing of rights of small members of agricultural cooperatives.

Despite its advantages, cooperation in agriculture also displays some drawbacks. Liang and Hendrikse [46], while investigating pricing strategies of agricultural cooperatives, show that in some cases voluntary cooperation may be harmful both to the entering member of a cooperative and to the cooperative as a whole. Poor performance of agricultural cooperatives, determined by improper organizational structure of this economic entity, was also documented by Kontogeorgos et al. [47]. Shumeta and D'Haese [48] found a positive effect of participation in cooperatives to food security and transfer of innovations, but showed that there is no evidence of a positive correlation between participation in cooperative activities and farmer income level. Bijman [49] documents success factors of cooperatives from the Netherlands but comes to the conclusion that they are being driven by successful internal and external circumstances. However, this is not because of such form of voluntary participation, which may be harmful to its members if applied directly. Iliopoulos et al. [50] documented the limited learning capacity of cooperatives, which is tied with the ability to learn of the least capable member of an agricultural cooperative.

\subsection{Government Incentives towards Cooperation in Agriculture}

Social and economic policy implemented by the government as well as legislation is recognized as one of the main factors influencing the development of cooperatives [51]. Appropriate policy and legal framework are vital for successful agricultural cooperatives [52]. In general, the government can act as a promoter and facilitator by generating policies and programmes to support cooperatives, developing adequate infrastructure and social services, and eliminating any barriers to cooperative development [53-55]. Public policy support can also gain more specific forms.

The areas of public policy support may include human resource development, research and management consultancy, accountancy and auditing, information technology, laws and taxation, and relations with the private sector [56]. Education and training provided by the state before and after establishing a cooperative is of crucial importance among those areas [57].

In most market-oriented economies with advanced agricultural sectors, cooperatives receive public support in the form of: (1) provision of a flexible legal framework that does not discriminate against cooperatives in any way, (2) exemption from antitrust laws, (3) beneficial tax treatment, (4) the access to favourable credit terms, and (5) technical assistance [52].

In addition to aforementioned support forms, farmers in cooperatives need to access sufficient land, infrastructure, information and networks in order to succeed in business, since cooperatives are not always able to cover these needs.

Some authors suggest a more structured view on public policy support enhancing cooperation. According to Chen and Scott [58], Government can support cooperatives in tangible and intangible forms, where intangible forms refer to hosting mobilization meetings, providing technical training, 
arranging site visits for members, assisting in and providing subsidies for certifications for various high quality food standards, providing tax exemptions and other kinds of financial support, and public recognition to selected cooperatives as a reward for their good performance, which is perceived as a tangible support in terms of changes in cooperative attitude [59]. Public policy measures can also be categorized as direct, for instance, in the form of subsidies or grants, or indirect, as provisions in business and organization law that makes it relatively easy to establish a cooperative [14].

One of the most inclusive and comprehensive categorizations of agricultural cooperative related policy measures is presented by Bijman et al. [14], who follows the typology of general policy measures, consisting of mandates, inducements, capacity building and system changing:

1. Cooperative legislation/incorporation law (refers to mandates),

2. Market regulation and competition policies (refers to inducements),

3. Financial and other incentives (e.g., tax exemption, access to favourable credit, etc.) (refers to inducements),

4. Technical assistance (refers to capacity building),

5. Other.

Government effort to support cooperation should not be taken for granted. On the contrary, it is usually rationally grounded. The four most frequent justifications for public policy support of cooperatives [52] are:

1. Agricultural cooperatives provide farmers with an institutional mechanism that increases their bargaining power vis-à-vis their partners in the food supply chain and corrects excess supply induced prices;

2. Cooperatives address various forms of market failures and, as a result, provide their members with countervailing power. In this role, cooperatives improve market performance;

3. They improve the coordination of supply with demand for farm commodities to achieve prices more consistent with costs of production, and

4. Cooperatives are instrumental in achieving community development goals and facilitating the integration of low-income producers into community life.

Traditionally, cooperatives' ability to address market failures as justification for public policy support has prevailed, but cooperatives have proven to be instrumental in addressing a number of other major agricultural marketing issues such as enabling price determination and discovery, achieving price and income stability, improving subsector coordination, securing market access to disadvantaged farmers, and maintaining farmer control of sectors [52]. Therefore, more and more public policy designers take into consideration all of those public or quasi-public goods for the benefit of members and communities produced and distributed by agricultural cooperatives.

On the other hand, even justified state interference in the cooperative development can be positive as well as negative [60]. Experience has shown that government policies can both enhance and impede independent cooperative development. Direct intervention in the establishment and operation of cooperatives undermines personal drive and motivation of its members, which is the key factor of success in cooperative business $[61,62]$. Cooperatives created from the bottom up, through initiatives in rural areas, are more successful than those established through government programs [56]. Another problem related to promoting cooperative activity through positive inducements and incentives (for example, subsidies) are the possibility to attract non-cooperative end-users that use a cooperative as a tool to avoid the payment of taxes [63]. Therefore, public policy support must be limited and targeted to the needs of cooperatives.

Finally, not all notably supportive policy measures improve cooperatives' competitive position. Brusselaers et al. [17] explain that this occurs due to two distinct reasons: unawareness by the target group, i.e., cooperatives, of the existence of policy measures or ignorance by the government of the specific nature and purpose of agricultural cooperatives. 


\section{Measures to Support the Development of Cooperatives in Lithuania}

In most market-oriented and smart agricultural sector economies, cooperatives receive public intangible and tangible forms of support. Experience shows that public policy can enhance and hinder the development of independent farmers in collaboration and cooperation. Direct intervention in the creation and operation of cooperatives can undermine motivation to collaborate, which is a key factor for a successful cooperative business. Another problem with the promotion of cooperation is the possibility of attracting only those seeking financial support who use cooperative status as a tool for state support rather than as a means of cooperation. Policy measures therefore need to be more focused on the needs of cooperatives, taking into account the characteristics of the knowledge economy, when production is treated as a service, production organization as management decisions, and resources as knowledge and wealth.

Out of 17 cooperation measures applied in Lithuania, according to the typology of policy measures proposed by McDonnell and Elmore [64], 76\% are attributable to the type of financial incentives. The least tools are for empowerment, system change and capacity building (Figure 1).

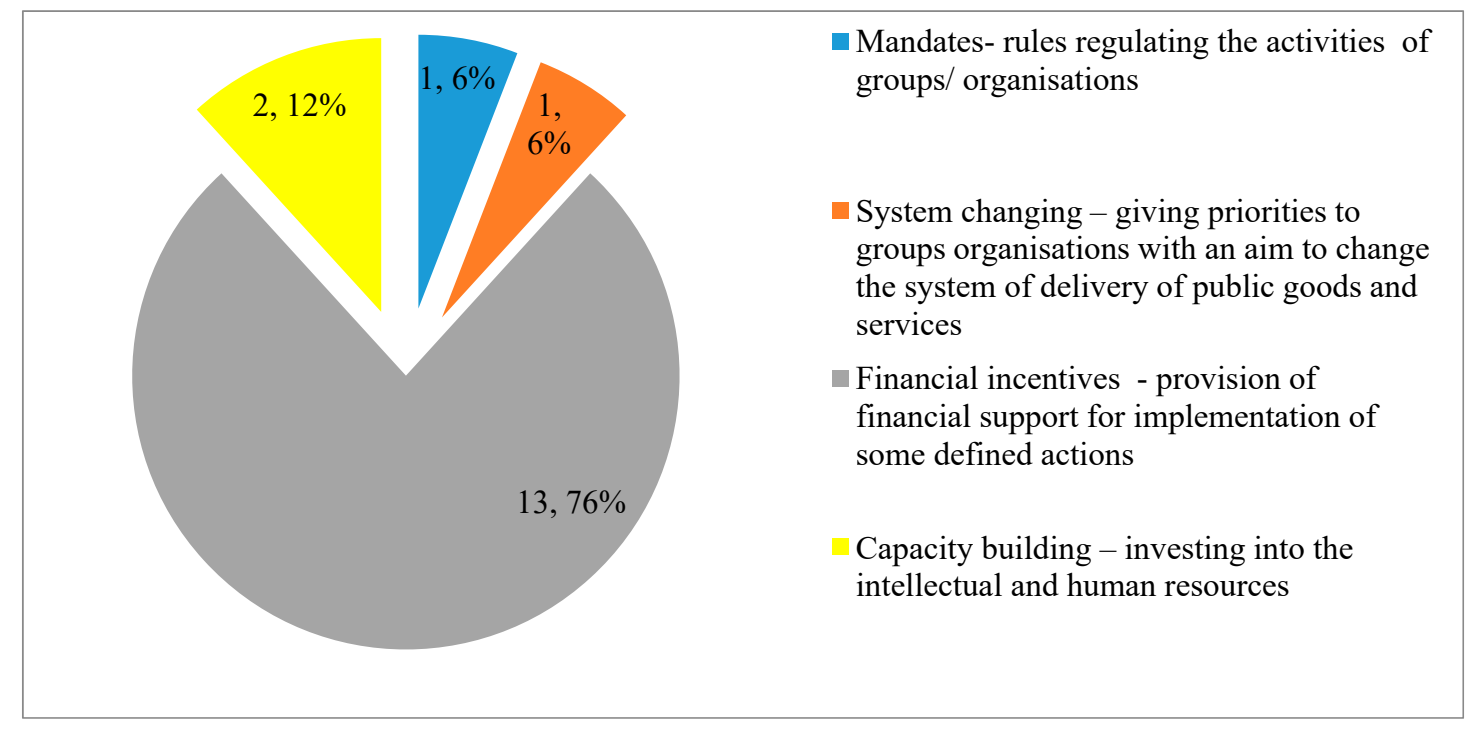

Figure 1. Distribution of cooperation policy measures in Lithuania by type of measures. Source: composed by the authors based on the typology of McDonnell and Elmore (1987).

Measures to promote the development of cooperation, which are attributed to the type of financial incentives, are financed by the European Union. European Union support for the development of co-operation in the Lithuanian agricultural sector was provided for the first time under the SAPARD program "Processing and marketing of agricultural and fishery products. Support is provided to cooperatives operating in the meat and fish processing sectors. According to the National Paying Agency, 5,673,081 EUR was allocated to the meat sector and 1,474,827 EUR to the fish sector.

During the period of implementation of the Single Programming Document (SPD) in 2004-2006, financial support was given to cooperatives processing agricultural products and improving marketing. For the cooperative(s) operating in the plant production sector, public support of 1,386,887 EUR was allocated for the installation of a modern primary rape processing workshop(s).

During the implementation period of the Lithuanian Rural Development Program 2007-2013, 41,969,633 EUR of public support was granted to agricultural cooperatives processing and improving marketing. The largest share of support was allocated to agricultural cooperatives operating in the crop sector-24,983,666 EUR. Agricultural cooperatives operating in the meat sector had received 16,942,524 EUR, while in other or several sectors-43,443 EUR.

According to the Lithuanian Rural Development Program 2014-2020 and according to the data of the National Paying Agency of November 2018, 14 projects of agricultural cooperatives were 
approved. In addition, $64.3 \%$ of projects were granted for investments in the processing, marketing and (or) development of agricultural products, $25.7 \%$-for investment in agricultural holdings (Table 1 ). All nine approved projects are aimed at increasing and improving grain processing and storage capacities. Moreover, there are 11 agricultural cooperative agricultural processing, marketing and (or) development investment projects that are still being evaluated.

Table 1. Projects approved for agricultural cooperatives financed by the Lithuanian Rural Development Program 2014-2020. Source: National Paying Agency data.

\begin{tabular}{|c|c|c|}
\hline Support Measure/Activity Area & $\begin{array}{l}\text { Number of Approved } \\
\text { Projects/Amount of Support }\end{array}$ & Funded Expenses \\
\hline $\begin{array}{l}\text { Support for investment in the } \\
\text { processing, marketing and (or) } \\
\text { development of agricultural } \\
\text { products }\end{array}$ & $\begin{array}{l}9 \text { projects } \\
19,297,797 \text { EUR }\end{array}$ & $\begin{array}{ll}\text { - } & \text { plant processing, storage } \\
\text { equipment, } \\
\text { marketing facilities; } \\
\text { - } \quad \text { milk processing, storage } \\
\text { equipment and techniques; } \\
\text { - } \quad \text { special equipment/tools for } \\
\text { transporting crop products; } \\
\text { building construction, } \\
\text { reconstruction, major repairs, } \\
\text { real estate improvement; } \\
\text { the equipment directly } \\
\text { related to the activity or the } \\
\text { entire production cycle; } \\
\text { - } \quad \text { other equipment/machinery; } \\
\text { - } \quad \text { general expenses }\end{array}$ \\
\hline $\begin{array}{l}\text { Support for investment in } \\
\text { agricultural holdings }\end{array}$ & $\begin{array}{l}5 \text { projects } \\
955,137 \text { EUR }\end{array}$ & 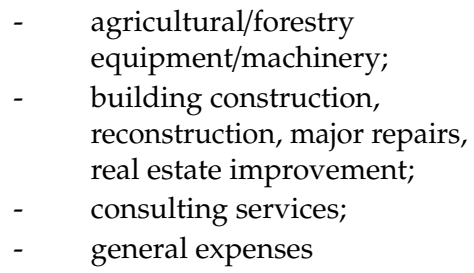 \\
\hline
\end{tabular}

According to the Lithuanian Rural Development Program 2014-2020, the members of the cooperatives were also given the opportunity to receive additional selection points for the support of individual measures. Members of cooperatives were using these possibilities sluggishly, except for members of cooperatives in the forest sector.

In order to improve the risk management of activities in agricultural cooperatives, Lithuanian agricultural cooperatives are also provided with credits and guarantees. Nevertheless, according to the 2014-2018 data of the Agricultural Credit and Guarantee Fund, agricultural cooperatives among all the fund's clients used the least amount of the services of this fund (Figure 2). 


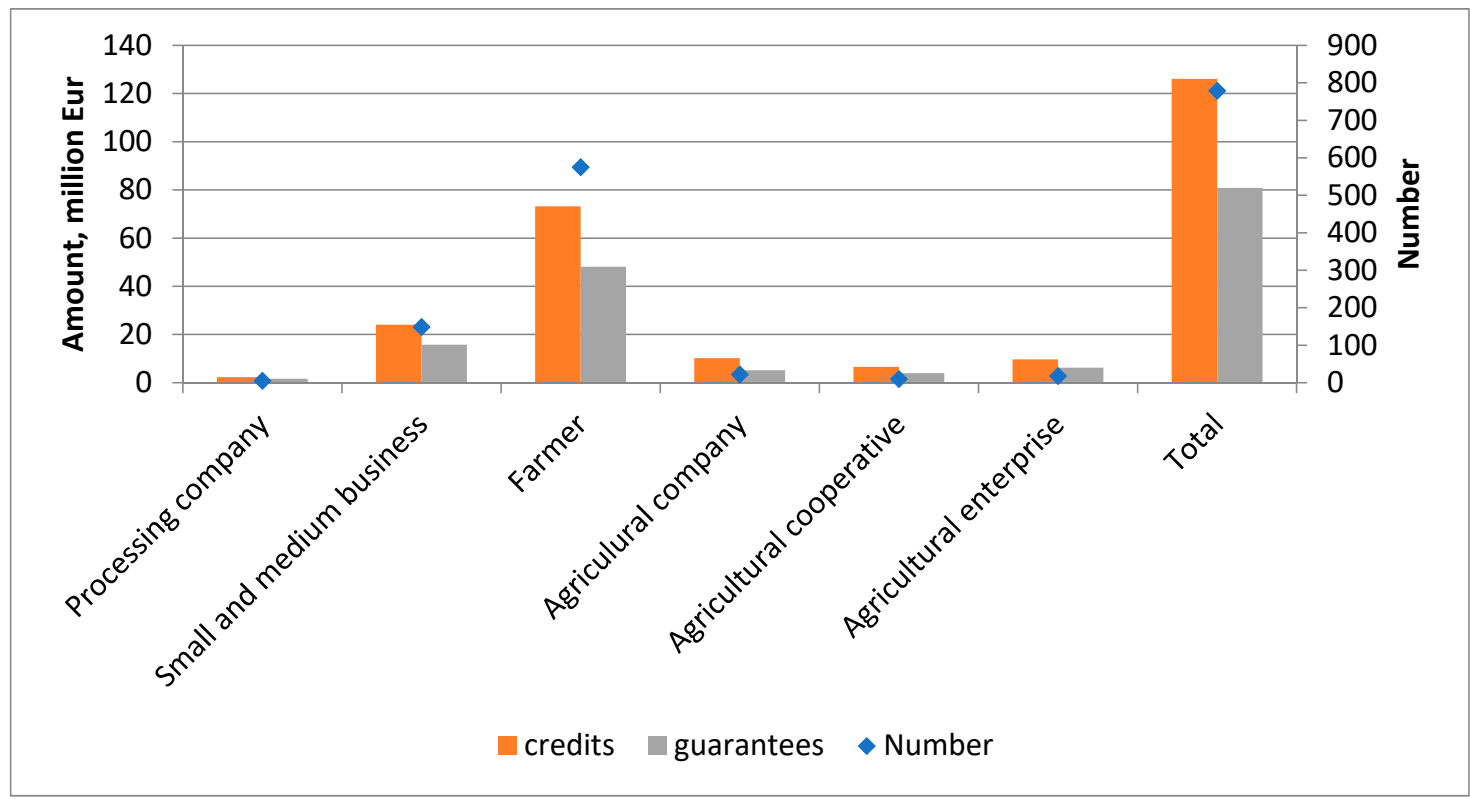

Figure 2. Credits and guarantees for agricultural entities in Lithuania, 2014-2018. Note: Guarantees are currently available to all cooperatives. Until 30 November 2016, guarantees were provided only to agricultural cooperative societies (cooperatives) recognized in accordance with the established procedure. Source: Agricultural Credit Guarantee Fund.

\section{Methods}

Expert interviews are an important but methodologically little noticed data gathering instrument in evaluation research. Quantitative results are frequently emphasized in the evaluations, since they are easier to exploit politically or as effective publicity and enable comparison with other programmes or policies [65]. On the other hand, expert evaluation is very valuable when an objective quantitative measurement is impossible or inappropriate. Therefore, according to Abels and Behrens [66], expert interviews are "vitally important" to policy research, especially in evaluative analysis.

Expert interviews have significant advantages over other methods of data collection.

First, due to the lack of other data sources or reasons of efficiency, certain questions can only be addressed by involving experts. Second, interviews with different well-informed respondents make it possible to take differing points of view into account and to reveal possible areas of conflict. Third, access to information in the evaluation process is made easier and acceptance of the results is increased [65].

The main criterion for setting up of the group of experts is its ability to resolve research problems in a reliable and effective way. Reliability of expert evaluation depends on the size of the group, i.e., the number of experts, and its composition according to the following criteria: position, related to the research topic, work experience in the subject in question, the degree of quality of prior expert judgements, the level of public recognition, and objectivity of the submitted evaluation [67]. Experts of suitable competence for policy evaluation are usually involved in conception and planning, implementation as well as in changes to and further developments of the policy. Experts should include both decision-makers and implementers without decision-making authority. As for the sufficient number of experts, a quantitative research should rely on seven to ten experts, while the qualitative research may rely on five experts at least [68]. The threshold of five experts as a sufficient number for qualitative studies was also reported by Libakova and Sertakova [67].

Initially, nine experts (E1 to E9) were selected for the survey in Lithuania. The experts were selected on the basis of their occupational position, involvement in the formation of cooperation policy or its improvement on academic or practical level as well as their work experience in the field of research and knowledge. Therefore, the initial list of experts consisted of all main opinion leaders on 
cooperation in Lithuania: specialists/representatives of Cooperation unit of the Ministry of Agriculture of the Republic of Lithuania (coded as E1-E3), researchers from different universities (coded as E4-E7), a specialist/representative of Cooperation and Law Department of the Chamber of Agriculture of the Republic of Lithuania (coded as E8), and the head of Consultancy Agency (coded as E9). Experts E3, E7 and E9 did not respond. Thus, the results of the study are based on the answers of the remaining six experts. The six experts responded to the survey include representatives of the Cooperation Department of the Ministry of Agriculture of the Republic of Lithuania (E1 and E2), representatives of higher education and training institutions (E4-E6), and a representative of the Department of Cooperation and Law of the Agricultural Chamber of the Republic of Lithuania (E8). Thus, the expert survey includes academia, policy makers and businessmen representatives. The description of the experts is given in Table 2 below.

Table 2. Experience of the experts' indifferent areas (years).

\begin{tabular}{|c|c|c|c|c|}
\hline Expert & Science & Policy Making & Business & Qualification \\
\hline E1 & & 11 & & $\begin{array}{c}\text { Cooperation Development Specialist at } \\
\text { the Ministry of Agriculture of the } \\
\text { Republic of Lithuania }\end{array}$ \\
\hline E2 & & 17 & & $\begin{array}{c}\text { Cooperative Development Specialist of } \\
\text { the Ministry of Agriculture of the } \\
\text { Republic of Lithuania }\end{array}$ \\
\hline E4 & 10 & & & $\begin{array}{l}\text { Ph.D. in Social Sciences, Head of Rural } \\
\text { Development Department at a } \\
\text { research institute }\end{array}$ \\
\hline E5 & 31 & & & Professor, Ph.D. in Social Sciences \\
\hline E6 & 13 & & & Professor, Ph.D. in Social Sciences \\
\hline E8 & & & 10 & $\begin{array}{c}\text { Head of the Cooperative and Legal } \\
\text { Division of the Chamber of Agriculture of } \\
\text { the Republic of Lithuania }\end{array}$ \\
\hline
\end{tabular}

The number of experts participating in the survey is rather limited due to the size of the pool of experts engaged in agricultural cooperation in Lithuania. Thus, the experts involved have genuine knowledge on the issue and do not deliver too general responses. Anyway, the three major groups (policy makers, academia and business) are represented, thus ensuring that the interests of different stakeholders are identified.

A semi-structured survey method was chosen to collect expert data. Interviews with selected experts were conducted in the period of 15-25 May 2018. Experts were provided with a list of 17 policy measures promoting cooperation in Lithuania, compiled on the basis of legal documents, as well as interview questions. A survey questionnaire was formulated to include the following aspects: evaluation of the effect of each policy measure on the development of agricultural cooperatives whether it promotes or hinders it or has none of the mentioned effects and is considered as unnecessary; other policy measures that, according to experts, have an effect on the development of cooperatives and should have been included in the submitted list; policy measures that are applied in other countries and would be useful in the Lithuanian case; the necessity and reasonability of public policy support for the development of cooperatives as one of the business organization form, and the overall evaluation of Lithuanian policy promoting cooperation in agriculture. Experts were asked to give a reasoned opinion on every interview question.

\section{Results}

Experts assessed the impact of each of the 17 policy measures on the development of cooperatives in Lithuania. Specifically, they were asked whether a particular measure promotes, hinders or neither 
promotes nor hinders the development of cooperatives. Thus, we not only looked at the operation of already established cooperatives, but also considered the obstacles for development of the new ones in Lithuania.

The policy instrument-the Law on Cooperative Companies (Cooperatives), M-I (1), of the Republic of Lithuania, which can be classified as a mandate type of measure-was evaluated as promoting the development of cooperatives by four out of six experts. Further on, two out of six experts (E2 and E8) pointed out that this measure neither promotes nor hinders the development of cooperatives. According to the experts, the Law on Cooperative Companies (Cooperatives), M-I (1), of the Republic of Lithuania regulates the necessary legal aspects of the establishment and operation of cooperative societies (cooperatives), thus creating legal preconditions for companies of this form to start and operate. However, it covers only one form of cooperation while, both in theory and in practice, there are many other forms of cooperation.

Another policy instrument-the Order of the Minister of Agriculture of the Republic of Lithuania on the Procedure for Recognition of Cooperative Companies (Cooperatives) for Agricultural Cooperative Companies (Cooperatives), which can be classified as a system changing measure-was rated as promoting the development of cooperation, as five out of six experts. One of six experts (E2) indicated that this measure neither promotes nor hinders the development of cooperatives. According to the experts, not every established cooperative meets the classic definition and characteristics of a cooperative. When granting state aid to agricultural cooperatives, selected agricultural cooperatives must match the characteristics of the agricultural cooperative. On one hand, this approach may not promote (or even hinder) the development of cooperatives, but, on the other hand, it can help to purposefully identify and provide support to agricultural cooperatives.

In Lithuania, two policy measures are implemented, which can be classified as capacity building policy measures. Both measures were assessed by three experts as promoting the development of cooperatives, while three experts (E1, E2, and E8) noted that these measures neither promote nor hinder the development of cooperatives, as they do not target cooperatives exclusively. Experts who assessed the capacity building measures as promoting the development of cooperatives (E4-E6) note that these measures have the potential to promote the development of cooperatives, depending on the pro-activeness of participants of the process of cooperatives' development, the relevance of the topic and the quality of training programs and the actual training process.

In Lithuania, the support for agricultural cooperatives is provided under 13 policy measures, M-F (1) to M-F (13), which can be classified as financial incentives. All experts assessed 10 measures, M-F (3) to M-F (6) and M-F (8-13), as promoting the development of co-operation. One expert (E5) assessed that these three measures neither hinder nor promote the development of cooperatives. The expert believes that the provisions of the Law on Income Tax, M-F (1), and the Law on the Real Estate Tax, M-F (2), of the Republic of Lithuania do not correspond to the essence of the agricultural cooperatives. According to the classic definition of agricultural cooperatives, cooperatives do not engage in the production of agricultural products, but create added value through joint processing and sales of agricultural products and so on. The Law on Income Tax, M-F (1), provides a preferential tax on profits when, over the tax period, more than 50 percent of the income comes from agricultural activities, that is to say, the production of agricultural products. Such a provision promotes the concentration of agricultural production in cooperatives, but not the development of their activities according to their actual purpose. According to the opinion of the expert, the application of the reduced profit tax can be applied to those cooperatives which have more than $50 \%$ of the profits turnover consisting of purchases of goods and services of cooperative members from a cooperative and sales of agricultural products to a cooperative (Table 3). 
Table 3. Distribution of experts according to the assessment of the impact of policy measures implemented in Lithuania on the development of cooperatives.

\begin{tabular}{|c|c|c|c|}
\hline \multirow[b]{2}{*}{ Code of the Measure } & \multicolumn{2}{|c|}{ Expert Evaluation } & \multirow{2}{*}{$\begin{array}{c}\text { Share of Experts Stating } \\
\text { That a Measure Promotes } \\
\text { Cooperation (\%) }\end{array}$} \\
\hline & $\begin{array}{c}\text { A Measure Promotes } \\
\text { Cooperation }\end{array}$ & $\begin{array}{l}\text { A Measure Has } \\
\text { Uncertain Effect }\end{array}$ & \\
\hline \multicolumn{4}{|c|}{ Mandates-rules regulating the activities of groups/organisations } \\
\hline M-I (1) & E1, E4, E5, E6 & E2, E8 & 66.7 \\
\hline \multicolumn{4}{|c|}{$\begin{array}{c}\text { System changing-giving priorities to groups organisations with an aim to change the system of delivery of } \\
\text { public goods and services }\end{array}$} \\
\hline M-S (1) & $\mathrm{E} 1, \mathrm{E} 4, \mathrm{E} 5, \mathrm{E} 6, \mathrm{E} 8$ & E2 & 83.3 \\
\hline \multicolumn{4}{|c|}{ Capacity building-investing into the intellectual and human resources } \\
\hline M-G (1) & E4, E5, E6 & $\mathrm{E} 1, \mathrm{E} 2, \underline{\mathrm{E} 8}$ & 50.0 \\
\hline M-G (2) & $\mathrm{E} 4, \mathrm{E} 5, \mathrm{E} 6$ & $\mathrm{E} 1, \mathrm{E} 2, \underline{\mathrm{E} 8}$ & 50.0 \\
\hline \multicolumn{4}{|c|}{ Financial incentives-provision of financial support for implementation of some defined actions } \\
\hline M-F (1) & E1, E2, E4, E6, E8 & E5 & 83.3 \\
\hline M-F (2) & E1, E2, E4, E6, E8 & E5 & 83.3 \\
\hline M-F (3) & E1, E2, E4, E5, E6, E8 & & 100 \\
\hline $\mathrm{M}-\mathrm{F}(4)$ & E1, E2, E4, E5, E6, E8 & & 100 \\
\hline M-F (5) & E1, E2, E4, E5, E6, E8 & & 100 \\
\hline M-F (6) & E1, E2, E4, E5, E6, E8 & & 100 \\
\hline $\mathrm{M}-\mathrm{F}(7)$ & $\mathrm{E} 1, \mathrm{E} 2, \mathrm{E} 4, \mathrm{E} 6, \mathrm{E} 8$ & E5 & 83.3 \\
\hline M-F (8) & E1, E2, E4, E5, E6, E8 & & 100 \\
\hline M-F (9) & E1, E2, E4, E5, E6, E8 & & 100 \\
\hline M-F (10) & E1, E2, E4, E5, E6, E8 & & 100 \\
\hline M-F (11) & E1, E2, E4, E5, E6, E8 & & 100 \\
\hline M-F (12) & E1, E2, E4, E5, E6, E8 & & 100 \\
\hline M-F (13) & E1, E2, E4, E5, E6, E8 & & 100 \\
\hline
\end{tabular}

The six experts participated in the survey: E1 and E2 are representatives of the Cooperation Department of the Ministry of Agriculture of the Republic of Lithuania; E4-E6 - representatives of higher agricultural education and training institutions; E8-representative of the Department of Cooperation and Law of the Agricultural Chamber of the Republic of Lithuania. Experts assessed separately the impact of each of the 17 policy measures on the development of cooperatives in Lithuania, in terms of whether the measure promotes, hinders or neither promotes nor hinders the development of cooperatives. Source: prepared by authors based on the information provided by experts.

None of the experts noted that any of the policy measures implemented in Lithuania to promote the development of cooperatives actually hinders the process of the development of cooperatives. In order to promote the development of cooperatives in the agricultural sector, experts with codes E5, E6 and E8 suggested expanding the list of existing policy measures. According to the experts, in Lithuania, cooperation in the agricultural sector is associated only with one organisational form-cooperatives. Their activities are legally regulated, and there is a system established to promote the activities of cooperatives; however, other forms of cooperation, which farmers may understand better and apply more often are neglected. According to the expert, it is important to have a legal base and support system for different forms of cooperation in the agricultural sector. Expert E8 suggested exempting the services provided by the cooperatives to their members from the value added taxes and providing support for the employment opportunities within the cooperative.

The E5 expert was more sceptical about the policy of promotion of agricultural cooperatives, as implemented in Lithuania. According to the expert, the external conditions of agricultural business, especially in the higher supply chains, are unfavourable for the development of cooperatives and 
therefore the policy of supporting agricultural cooperatives must be more segmented and targeted to those sectors where business external factors create lower barriers to the development of cooperatives. The expert $\mathrm{E} 4$ believes that farmers do not benefit from a plethora of policy measures, as the support is often channelled into insignificant, short-term projects, and therefore does not contribute to long-term value creation and does not improve or only slightly improves farmers' welfare. In the opinion of the expert, some cooperatives are being established only with the purpose to benefit from support. According to the E8 expert, the policy of supporting agricultural cooperatives in Lithuania could be more pro-active, more focused on providing support for leaders of the cooperatives' development process, and proving support for administration of the cooperatives at the beginning of their activities.

In the opinion of all the experts who participated in the survey, support measures for the development of agricultural cooperatives should continue being implemented. In the opinion of expert E1, cooperatives should be allowed to carry out their activities and receive support, but should not be given priority above other entities. According to the E5 expert, state support for agricultural cooperatives should primarily be directed towards the enhancing of the competitive power of small and medium-sized farms in the market, and reducing the risk of joint operations and joint management by systematically assessing the external and internal factors that have a critical impact on business.

Even though Cholupkova et al. [69] already acknowledged that social capital plays a crucial role in the establishment and operation of agricultural cooperatives, our study shows some misalignment among desirable and actual effects of the cooperation support policies in Lithuania in this regard. More specifically, the current public support measures aim at promoting internal social capital (e.g., training activities of the members of cooperatives), yet the inclusion of the external social capital into the activities of the cooperatives is not being supported. In order to further develop cooperation activities in Lithuania, the cooperatives should be allowed for a more versatile use of the support funds.

Lithuania is distinct from the other EU Member States in terms of the mix of the public policy measures for promoting agricultural cooperation. Specifically, Table 3 listed 17 measures with 13 of them being financial ones. Indeed, the opposite is observed for such countries as Poland [70], Belgium [71], France [72], Germany [73], or Austria [74], where institutional measures prevail. Thus, this finding once again confirms that Lithuania is required to pay more attention for improvement of the institutional setting in order to improve the effective agricultural cooperation activities. The improved institutional setting should correspond to the principles of network society.

\section{Conclusions}

Lithuania is lagging behind in comparison with other European Union countries in terms of agricultural entities cooperation. In addition, much of the earlier literature focuses on the operation of the cooperatives rather than the establishment thereof. This paper attempted to shed light on the major factors affecting creation and operation of the agricultural cooperatives. The limited use of financial incentives provided to cooperatives by Government is being observed along with a relatively high number of financial policy measures implemented by the Lithuanian government to support cooperatives. This suggests that certain financial measures are not effective. This can be explained by a number of factors, including the lack of knowledge of cooperatives on policy measures and the objectives of the operation of certain cooperatives.

According to the expert evaluation, policy measures implemented in Lithuania mostly promote or have a neutral impact on the development of cooperatives. The impact of policy measures being implemented in Lithuania to support cooperatives largely depends on the external conditions of agribusiness development. The majority of policy measures, according to experts, have the potential to stimulate the development of cooperatives, which is not fully used. In order to enhance the impact of these policy measures on the development of cooperatives, it is necessary to pursue targeted policy measures which would allow for supporting specific segments of the agricultural markets.

The major issue identified during the expert survey is that the institutional environment focuses on the traditional concept of the cooperatives, which is related to a formal institution of a legal entity. 
Furthermore, production activities are supported in most instances. These premises are typical for traditional modes of production, yet are not relevant for the modern economy involving sharing economics and outsourcing. In addition, a high concentration in the downstream markets precludes production-oriented cooperatives from meeting their objectives. Thus, the cooperation support policy in Lithuania should aim at supporting less formal groups of farmers and seek to correspond to the bottom-up approach.

The present paper embarked on the analysis of the aggregate statistical data and qualitative analysis based on the expert survey. However, further research could aim to identify the patterns of farmers and farmers' organisations inclined for cooperation [75-77].

Author Contributions: Investigation, D.Š.; Methodology, A.V. and D.S.; Writing—original draft, E.R.; Writing—review and editing, T.B. and M.M.

Funding: This research received no external funding.

Conflicts of Interest: The authors declare no conflict of interest.

\section{References}

1. Fałkowski, J.; Chlebicka, A.; Łopaciuk-Gonczaryk, B. Social relationships and governing collaborative actions in rural areas: Some evidence from agricultural producer groups in Poland. J. Rural Stud. 2017, 49, 104-116. [CrossRef]

2. Czyżewski, B.; Matuszczak, A.; Miśkiewicz, R. Public goods versus the farm price-cost squeeze: shaping the sustainability of the EU's common agricultural policy. Technol. Econ. Dev. Eco. 2019, 25, 82-102. [CrossRef]

3. Bernard, T.; Spielman, D.J. Reaching the rural poor through rural producer organizations? A study of agricultural marketing cooperatives in Ethiopia. Food Policy 2009, 34, 60-69. [CrossRef]

4. Cook, M.L. The future of US agricultural cooperatives: A neo-institutional approach. Am. J. Agric. Econ. 1995, 77, 1153-1159. [CrossRef]

5. Yadoo, A.; Cruickshank, H. The value of cooperatives in rural electrification. Energy Policy 2010, 38, 2941-2947. [CrossRef]

6. Bauwens, T.; Gotchev, B.; Holstenkamp, L. What drives the development of community energy in Europe? The case of wind power cooperatives. Energy Res. Soc. Sci. 2016, 13, 136-147. [CrossRef]

7. Bauwens, T.; Defourny, J. Social capital and mutual versus public benefit: The case of renewable energy cooperatives. Ann. Public Coop. Econ. 2017, 88, 203-232. [CrossRef]

8. Liu, F.F.; Zhou, Y.Q.; Zhang, Z.K.; Zhou, T.F. Research on energy structure and development strategy from 2010 to 2015 in Qingdao, China. Chin. J. Pop. Res. Env. 2017, 15, 239-248. [CrossRef]

9. Zhu, J. The 2030 Agenda for Sustainable Development and China's implementation. Chin. J. Pop. Res. Env. 2017, 15, 142-146. [CrossRef]

10. Russell, L.A.; Briggeman, B.C.; Featherstone, A.M. Financial leverage and agency costs in agricultural cooperatives. Agric. Financ. Rev. 2017, 77, 312-323. [CrossRef]

11. Wilson, E.W. Cooperatives: The First Social Enterprise. Depaul L. Rev. 2016, 66, 1013.

12. Benos, T.; Kalogeras, N.; Verhees, F.J.; Sergaki, P.; Pennings, J.M. Cooperatives' organizational restructuring, strategic attributes, and performance: The case of agribusiness cooperatives in Greece. Agribusiness 2016, 32, 127-150. [CrossRef]

13. Rostamzadeh, R.; Esmaeili, A.; Nia, A.S.; Saparauskas, J.; Ghorabaee, M.K. A Fuzzy Aras Method for Supply Chain Management Performance Measurement in SMEs under Uncertainty. Transform. Bus. Econ. 2017, 16, 319-348.

14. Bijman, J.; Iliopoulos, C.; Poppe, K.J.; Gijselinckx, C.; Hagedorn, K.; Hanisch, M.; Hendrikse, G.W.J; Kuhl, R.; Ollila, P.; Pyykkonen, P.; et al. Support for Farmers' Cooperatives; Final Report; Wageningen UR: Wageningen, The Netherlands, 2012; p. 127.

15. Bijman, J.; Iliopoulos, C. Farmers' Cooperatives in the EU: Policies, Strategies, and Organization. Ann. Public Coop. Econ. 2014, 85, 497-508. [CrossRef]

16. Hagedorn, K. Post-Socialist Farmers' Cooperatives in Central and Eastern Europe. Ann. Public Coop. Econ. 2014, 85, 555-577. [CrossRef] 
17. Brusselaers, J.; Poppe, K.; Azcarate, T.G. Do Policy Measures Impact the Position and Performance of Farmers' Cooperatives in the EU? Ann. Public Coop. Econ. 2014, 85, 531-553. [CrossRef]

18. Talmon, Y. Family and Community in the Kibbutz; Harvard University Press: Cambridge, MA, USA, 1972; Volume 67.

19. Rábín, A.Í. Growing Up in the Kibbutz; Springer: New York, NY, USA, 2013.

20. Hanson, P. The Rise and Fall of the the Soviet Economy: An Economic History of the USSR 1945-1991; Routledge: London, UK, 2014.

21. McCauley, M. Khrushchev and the Development of Soviet Agriculture: Virgin Land Program, 1953-1964; Springer: New York, NY, USA, 2016.

22. Fonte, M.; Cucco, I. Cooperatives and alternative food networks in Italy. The long road towards a social economy in agriculture. J. Rural Stud. 2017, 53, 291-302. [CrossRef]

23. Dillahunt, T.R.; Malone, A.R. The promise of the sharing economy among disadvantaged communities. In Proceedings of the 33rd Annual ACM Conference on Human Factors in Computing Systems, Seoul, Korea, 18-23 April 2015; pp. 2285-2294.

24. Kurakin, A.; Visser, O. Post-socialist agricultural cooperatives in Russia: A case study of top-down cooperatives in the Belgorod region. Post-Communist Econ. 2017, 29, 158-181. [CrossRef]

25. Rao, H.; Greve, H.R. Disasters and community resilience: Spanish flu and the formation of retail cooperatives in Norway. Acad. Manag. J. 2018, 61, 5-25. [CrossRef]

26. Shrestha, K. Cooperatives and Agriculture in Buddhism. Res. Nepal J. Dev. Stud. 2018, 1, 169-177. [CrossRef]

27. Wang, S.L. Cooperative extension system: Trends and economic impacts on US agriculture. Choices 2014, $29,1$.

28. Ert, E.; Fleischer, A.; Magen, N. Trust and reputation in the sharing economy: The role of personal photos in Airbnb. Tour. Manag. 2016, 55, 62-73. [CrossRef]

29. Zervas, G.; Proserpio, D.; Byers, J.W. The rise of the sharing economy: Estimating the impact of Airbnb on the hotel industry. J. Mark. Res. 2017, 54, 687-705. [CrossRef]

30. Edelman, B.; Luca, M.; Svirsky, D. Racial discrimination in the sharing economy: Evidence from a field experiment. Am. Econ. J. Appl. Econ. 2017, 9, 1-22. [CrossRef]

31. Martin, C.J. The sharing economy: A pathway to sustainability or a nightmarish form of neoliberal capitalism? Ecol. Econ. 2016, 121, 149-159. [CrossRef]

32. Hamari, J.; Sjöklint, M.; Ukkonen, A. The sharing economy: Why people participate in collaborative consumption. J. Assoc. Inf. Sci. Technol. 2016, 67, 2047-2059. [CrossRef]

33. Schor, J.B.; Fitzmaurice, C.; Carfagna, L.B.; Attwood-Charles, W.; Poteat, E.D. Paradoxes of openness and distinction in the sharing economy. Poetics 2016, 54, 66-81. [CrossRef]

34. Nobre, J.C.; Melchiors, C.; Marquezan, C.C.; Tarouco, L.M.R.; Granville, L.Z. A survey on the use of P2P technology for network management. J. Netw. Syst. Manag. 2018, 26, 189-221. [CrossRef]

35. Costello, M.A. Competitive Strategy Analysis for Agricultural Marketing Cooperatives; CRC Press: Boca Raton, FL, USA, 2019.

36. Lou, S. Research on the Evaluation of Rural Credit Cooperatives in Agriculture Efficiency in China's Various Regions. In Proceedings of the Fourth International Forum on Decision Sciences; Springer: Singapore, 2017; pp. 809-814.

37. Hale, J.; Carolan, M. Cooperative or uncooperative Cooperatives? Digging into the Process of Cooperation in Food and Agriculture cooperatives. J. Agric. Food Syst. Community Dev. 2018, 8, 1-20. [CrossRef]

38. Nestorov-Bizonj, J.; Kovljenić, M.; Erdelji, T. The Strategy for Agriculture and Rural Development of the Republic of Serbia in the Process of its Accession to the European Union. Strateg. Manag. 2015, 20, 57-66.

39. Mihnea, A.; Nikolov, D.N.; Kostenarov, K. Farms and Agricultural Enterprises for Development of Sustainable and Smart Cooperatives: A Multifactor Approach Using Digital Farm Management; IAFE-NRI: Stare Jabłonki, Poland, 2018.

40. Borgen, S.O.; Aarset, B. Participatory innovation: Lessons from breeding cooperatives. Agric. Syst. 2016, 145, 99-105. [CrossRef]

41. Sexton, R.J.; Sexton, T.A. Information-Sharing Cooperatives. Compet. Strategy Anal. For. Agric. Mark. Coop. Boulder 2019, 209. 
42. Simonović, Z.; Mihailović, B.; Milovanović, Z. Coperatives and farmers association as a model of entrepreneurship in serbian agriculture regarding the case of nisava district. Econ. Agric. 2018, 63, 699-712.

43. Lamine, C. Sustainability and resilience in agrifood systems: Reconnecting agriculture, food and the environment. Sociol. Rural. 2015, 55, 41-61. [CrossRef]

44. Swaminathan, M.S. Shaping Our Agriculture Future; Science Reporter: Chenai, India, 2018.

45. Zivkovic, S.; Hudson, D. Impact of the Relationship between Managers and the Board of Directors on Economic Performance of Agricultural Cooperatives. In Proceedings of the Southern Agricultural Economics Association (SAEA) 2015 Annual Meeting, Atlanta, Georgia, 31 January-3 February 2015. No. 1375-2016-109437.

46. Liang, Q.; Hendrikse, G. Pooling and the yardstick effect of cooperatives. Agric. Syst. 2016, 143, 97-105. [CrossRef]

47. Kontogeorgos, A.; Sergaki, P.; Kosma, A.; Semou, V. Organizational models for agricultural cooperatives: Empirical evidence for their performance. J. Knowl. Econ. 2018, 9, 1123-1137. [CrossRef]

48. Shumeta, Z.; D'Haese, M. Do Coffee Farmers Benefit in Food Security from Participating in Coffee Cooperatives? Evidence from Southwest Ethiopia Coffee Cooperatives. Food Nutr. Bull. 2018, 39, 266-280. [CrossRef]

49. Bijman, J. Agricultural Cooperatives in the Netherlands: Key success factors; International Summit of Cooperatives: Quebec City, QC, Canada, 2016.

50. Iliopoulos, C.; Cook, M.L.; Chaddad, F. Agricultural Cooperatives in Netchains. J. Chain. Netw. Sci. 2016, 16, 1-6. [CrossRef]

51. Stock, P.V.; Forney, J.; Emery, S.B.; Wittman, H. Neoliberal natures on the farm: Farmer autonomy and cooperation in comparative perspective. J. Rural Stud. 2014, 36, 411-422. [CrossRef]

52. Iliopoulos, C. Public Policy Support for Agricultural Cooperatives: An Organizational Economics Approach. Ann. Public Coop. Econ. 2013, 84, 241-252. [CrossRef]

53. Morfi, C.; Ollila, P.; Nilsson, J.; Feng, L.; Karantininis, K. Motivation behind members' loyalty to agricultural cooperatives. In Interfirm Networks; Springer: Cham, Switzerland, 2015; pp. 173-190.

54. Tortia, E.C.; Valentinov, V.L.; Iliopoulos, C. Agricultural cooperatives. J. Entrep. Organ. Divers. 2013, 2, $23-36$. [CrossRef]

55. Ortmann, G.F.; King, R.P. Agricultural cooperatives I: History, theory and problems. Agrekon 2007, 46, 18-46. [CrossRef]

56. Ruete, M. Inclusive Investment in Agriculture: Cooperatives and the Role of Foreign Investment. Invest. Agric. 2014, 2, 1-8.

57. Wang, X.; Gao, X.; He, R. Research on the Investment Cooperation between Sichuan and Chongqing Based on the Motives of Manufacturing Transformation and Upgrading. In Proceedings of the 4th International Symposium on Social Science (ISSS 2018), Dalian, China, 12-13 May 2018; Atlantis Press: Paris, France, 2018.

58. Chen, A.; Scott, S. Rural Development Strategies and Government Roles in the Development of Farmers' Cooperatives in China. J. Agric. Food Syst. Community Dev. 2014, 4, 35-55. [CrossRef]

59. Hakelius, K.; Hansson, H. Measuring changes in farmers' attitudes to agricultural cooperatives: Evidence from Swedish agriculture 1993-2013. Agribusiness 2016, 32, 531-546. [CrossRef]

60. Nuhanovic-Ribic, S. The Political Economy of Agricultural Cooperatives in Bosnia and Herzegovina: Towards a Sustainable Rural Development Model. Ph.D. Thesis, University of Trento, Trento, Italy, 2015.

61. Xu, X.; $\mathrm{Wu}, \mathrm{B}$. The Development of Chinese Co-operatives in Rural Areas. In Co-operative Innovations in China and the West; Palgrave Macmillan: London, UK, 2014; pp. 163-178.

62. Münkner, H.H. The Supportive Environment for Cooperatives in the Context of the Current Political, Economic, Social, Demographic and Ecological Environments. Prerequisites Process. Creat. 2002, 15-17.

63. Van der Sangen, G.J.H. How to Regulate Cooperatives in the EU? A Theory of Path Dependency. Dovenschmiddt Q. 2014, 2014, 131-146. [CrossRef]

64. McDonnell, L.M.; Elmore, R.F. Getting the job done: Alternative policy instruments. Educ. Eval. Policy Anal. 1987, 9, 133-152. [CrossRef]

65. Wroblewski, A.; Leitner, A. Between Scientific Standards and Claims to Efficiency: Expert Interviews in Programme Evaluation. In Interviewing Experts; Bogner, A., Littig, B., Menz, W., Eds.; Palgrave Macmillan: New York, NY, USA, 2009; pp. 235-251. 
66. Abels, G.; Behrens, M. Interviewing Experts in Political Science: A Reflection on Gender and Policy Effects Based on Secondary Analysis. In Interviewing Experts; Bogner, A., Littig, B., Menz, W., Eds.; Palgrave Macmillan: New York, NY, USA, 2009; pp. 138-156.

67. Libakova, N.M.; Sertakova, E.A. The Method of Expert Interview as an Effective Research Procedure of Studying Indigenous Peoples of the North. J. Sib. Fed. Univ. Hum. Soc. Sci. 2015, 1, 114-129. [CrossRef]

68. Bogner, A.; Littig, B.; Menz, W. (Eds.) Interviewing Experts; Springer: New York, NY, USA, 2009.

69. Chloupkova, J.; Svendsen, G.L.H.; Svendsen, G.T. Building and destroying social capital: The case of cooperative movements in Denmark and Poland. Agric. Hum. Values 2003, 20, 241-252. [CrossRef]

70. Matczak, P. Support for Farmers' Cooperatives; Country Report Poland; Wageningen UR: Wageningen, The Netherlands, 2012.

71. Gijselinckx, C.; Bussels, M. Support for Farmers' Cooperatives; Country Report Belgium; Wageningen UR: Wageningen, The Netherlands, 2012.

72. Filippi, M. Support for Farmers' Cooperatives; Country Report France; Wageningen UR: Wageningen, The Netherlands, 2012.

73. Kuhl, R. Support for Farmers' Cooperatives; Country Report Germany; Wageningen UR: Wageningen, The Netherlands, 2012.

74. Kuhl, R. Support for Farmers' Cooperatives; Country Report Austria; Wageningen UR: Wageningen, The Netherlands, 2012.

75. Chlebicka, A.; Pietrzak, M. Size of membership and survival patterns of producers' organizations in agriculture-Social aspects based on evidence from Poland. Sustainability 2018, 10, 2293. [CrossRef]

76. Markowska-Przybyła, U.; Ramsey, D. Social Capital and Long-Term Regional Development within Poland in the Light of Experimental Economics and Data from a Questionnaire. Sustainability 2018, 10, 3000. [CrossRef]

77. Sia, S.K.; Jose, A. Attitude and subjective norm as personal moral obligation mediated predictors of intention to build eco-friendly house. Manag. Environ. Qual. 2019, 30, 678-694. [CrossRef]

(C) 2019 by the authors. Licensee MDPI, Basel, Switzerland. This article is an open access article distributed under the terms and conditions of the Creative Commons Attribution (CC BY) license (http://creativecommons.org/licenses/by/4.0/). 